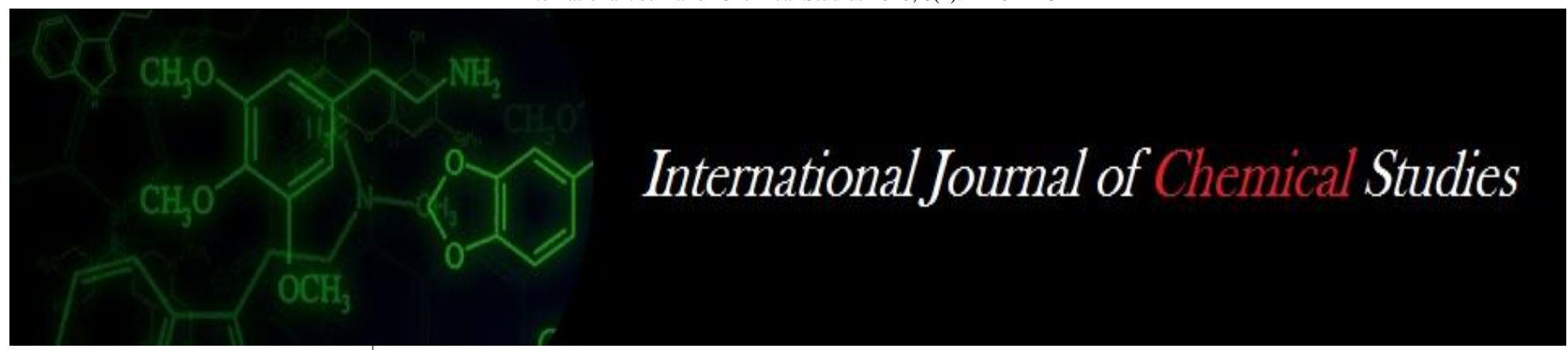

P-ISSN: 2349-8528

E-ISSN: 2321-4902

IJCS 2020; 8(1): 1140-1143

(C) 2020 IJCS

Received: 22-11-2019

Accepted: 24-12-2019

Patel BN

M.Sc. Scholar, Dept. of Soil

Science \& Agriculture.

Chemistry, NMCA, Navsari,

Gujarat, India

\section{Patel KH}

Associate Professor, Dept. of Soi

Science \& Agriculture.

Chemistry, NAU, Bharuch

Campus, Gujarat, India

Narendra Singh

Assistant Research Scientist,

Department of Soil Science,

NAU, Navsari, Gujarat, India

Alok Shrivastava

Associate Professor, Dept. of Statistics, College of Agriculture,

NAU, Bharuch Campus,

Gujarat, India

\section{Corresponding Author:}

Narendra Singh

Assistant Research Scientist,

Department of Soil Science,

NAU, Navsari, Gujarat, India

\section{Effect of $\mathrm{P}_{2} \mathrm{O}_{5}$, FYM and bio-fertilizer on nutrient content in soil after harvest of summer greengram (Vigna radiate $\mathrm{L}$. )}

\author{
Patel BN, Patel KH, Narendra Singh and Alok Shrivastava
}

DOI: https://doi.org/10.22271/chemi.2020.v8.i1o.8403

\begin{abstract}
A field experiment was conducted during 2018-19 to study the effect of phosphorus, FYM and biofertilizer on nutrient content in soil before and after harvest of summer greengram. There were twelve treatments comprising of three phosphorus levels [Control $\left(\mathrm{P}_{0}\right), 20 \mathrm{~kg} \mathrm{P}_{2} \mathrm{O}_{5} \mathrm{ha}^{-1}\left(\mathrm{P}_{1}\right)$ and $40 \mathrm{~kg}_{2} \mathrm{O}_{5} \mathrm{ha}^{-1}$ $\left(\mathrm{P}_{2}\right)$ ] combined with two FYM levels [control $\left(\mathrm{F}_{0}\right)$ and $5 \mathrm{t} \mathrm{FYM} \mathrm{ha-1}\left(\mathrm{F}_{1}\right)$ ] along with two levels of biofertilizer [control $\left(\mathrm{B}_{0}\right)$ and PSB inoculation $\left(\mathrm{B}_{1}\right)$ ]. Phosphorus applied in the form of SSP and PSB as seed inoculation. The experiment was laid out in factorial RBD with three replications. The recommended dose of $\mathrm{N}$ was applied uniformly to all the treatments. Residual availability of $\mathrm{P}$ increased due to phosphorus and PSB inoculation. Major and micro nutrients availability in soil was increased due to FYM treatment after harvesting. Organic carbon content was favourably influenced by FYM treatment. Interaction of P x F x B had synergistic effect on residual availability of P.
\end{abstract}

Keywords: Phosphorus, FYM, PSB, nutrient content

\section{Introduction}

Greengram (Vigna radiata L.) occupies prime position among pulses by virtue of its short growth period, high tonnage capacity and outstanding nutrient value as food, feed and forage. Among the pulses, greengram is one of the most important and extensively cultivated pulse crops. In India, greengram occupies an area of about 3.51 million hectares producing 1.80 million tonnes with the productivity of $511 \mathrm{~kg} \mathrm{ha}^{-1}$ (Anonymous, 2012) ${ }^{[1]}$, whereas in Gujarat it is grown over 2.40 lakh hectares with production of 1.28 lakh tonnes and productivity of 525 $\mathrm{kg} \mathrm{ha}^{-1}$ (Anonymous, 2012a) ${ }^{[2]}$.

Phosphorus $(\mathrm{P})$ is one of the most needed elements for pulse production. Phosphorus, although not required in large quantities, is critical to green gram yield because of its multiple effects on nutrition. Phosphorus plays a key role in various physiological processes like root growth and dry matter production, nodulation and nitrogen fixation and also in metabolic activities especially in protein synthesis.

Farm yard manure (FYM) application to the crop is an age old practice. The yield and nutritional quality of green gram is greatly improved by application of FYM and nutrient elements. FYM is known to play an important role in improving the fertility and productivity of soils through its positive effects on soil physical, chemical and biological properties of soils and balanced plant nutrition.

Phosphorus solubilizing microorganisms (bacteria and fungi) enable $\mathrm{P}$ to become available for plant uptake after solubilization. Several soil bacteria, particularly those belonging to the genera Bacillus and Pseudomonas and fungi belonging to the genera Aspergillus and Penicillium possess the ability to bring insoluble phosphates in soil into soluble forms by secreting organic acids such as formic, acetic, propionic, lactic, glycolic, fumaric, and succinic acids. These acids lower the $\mathrm{pH}$ and bring about the dissolution of bound forms of phosphates. Very high cost of phosphatic fertilizer also demand the need for recycling and exploitation of fixed phosphorus to improve crop production. The availability of phosphorus to the crop can be augmented by providing appropriate strains of microbes which are known to solubilise the fixed phosphorus and mobilize the deeply placed phosphorus to root zone by their activity. Besides increasing the availability of native $\mathrm{P}$ in the soil also help in enhancing the use 
efficiency of applied phosphorus (Thenua and Sharma, 2007) [11]. FYM additions were also found to mobilize the fixed phosphates in the soil thus increasing the available $\mathrm{P}$ to crops (Venkateswarlu, 2000) ${ }^{[12]}$.

\section{Materials and Methods}

A field experiment was conducted during summer season of 2018 at the college farm, Navsari Agricultural University, Navsari to study the "Phosphorus Management in greengram (Vigna radiate L.) under south Gujarat condition.". The soil of the experimental field was clay in texture having medium to poor drainage, medium in available nitrogen, available phosphorus and potash. Total twelve treatment combinations comprising of all possible treatments of three levels of phosphorus viz., $\mathrm{P}_{0}\left(0 \mathrm{~kg} \mathrm{P}_{2} \mathrm{O}_{5}\right.$ ha- $\left.^{1}\right), \mathrm{P}_{1}\left(20 \mathrm{~kg} \mathrm{P}_{2} \mathrm{O}_{5}\right.$ ha- $\left.^{1}\right)$ and $\mathrm{P}_{2}\left(40 \mathrm{~kg} \mathrm{P}_{2} \mathrm{O}_{5} \mathrm{ha}^{-1}\right)$, two levels of FYM viz., $\mathrm{F}_{0}\left(0 \mathrm{t} \mathrm{ha}^{-1}\right)$ and $\mathrm{F}_{1}\left(5 \mathrm{t} \mathrm{ha}^{-1}\right)$ and two levels of bio-fertilizer viz., $\mathrm{B}_{0}$ (No inoculation) and $\mathrm{B}_{1}$ (PSB inoculation) were tested in factorial randomized block design with three replications. Greengram variety Meha was sown by opening of furrow at a distance of $30 \times 10 \mathrm{~cm}$. The full dose of fertilizers was applied according to the treatments manually before sowing the seeds. PSB was applied as seed inoculation. The phosphorus was SSP. All the recommended cultural practices and plant protection measures were followed throughout the experimental periods.

\section{Result and Discussion \\ 3.1 Effect of phosphorus}

Post-harvest nutrient status of soil, in the case of available $\mathrm{N}$ and $\mathrm{K}_{2} \mathrm{O}$ in soil did not affect significantly by the effect of phosphorus application (table-2)

Available phosphorus status in soil (table-2) was significantly increase with phosphorus application and recorded significantly higher under the $\mathrm{P}_{2} @ 40 \mathrm{~kg} \mathrm{\textrm {P } _ { 2 }} \mathrm{O}_{5} \mathrm{ha}^{-1}(47.45$ kgha $^{-1}$ ) over $\mathrm{P}_{0}$ control. Treatment $\mathrm{P} 1$ significantly higher than control $\mathrm{P}_{0}$. Significantly higher values of available

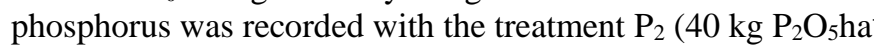
$\left.{ }^{1}\right)$ as compared to $\mathrm{P}_{1}\left(20 \mathrm{~kg} \mathrm{P}_{2} \mathrm{O}_{5} \mathrm{ha}^{-1}\right)$ and $\mathrm{P}_{0}\left(0 \mathrm{~kg} \mathrm{P}_{2} \mathrm{O}_{5} \mathrm{ha}^{-1}\right)$. The available $\mathrm{P}$ status of the soil after harvest of greengram was also improved with the addition of phosphorus and this might be due to residual effect of phosphatic fertilizer. Similar findings were also reported by Kokani et al. (2015) ${ }^{[5]}$ Nyekha et al. (2015) ${ }^{[7]}$ and Mohammad et al. (2017) ${ }^{[6]}$.

Data showed in table 4 stated that, all other nutrient content $(\mathrm{Ca}, \mathrm{Mg}, \mathrm{S}, \mathrm{Fe}, \mathrm{Mn}, \mathrm{Zn}$ and $\mathrm{Cu}$ ) was not significantly influenced by the application of phosphorus.

\subsection{Effect of FYM}

Data showed that the effect of FYM significantly influenced the available $\mathrm{N}$ in soil after harvest. Available $\mathrm{N}$ was recorded by treatment $\mathrm{F}_{1}$ was significantly higher over control $\mathrm{F}_{0}$. (Table-2). The increase in available $\mathrm{N}$ under organics treatment was expected due to addition of $\mathrm{N}$ through mineralization of organic matter. The results were in accordance with the finding of Jat et al.(2012a) ${ }^{[4]}$, Ranpariya et al. (2017) ${ }^{[9]}$ and Rekha et al. (2018) ${ }^{[10]}$.

Data in table 2, revealed that soil available $\mathrm{P}_{2} \mathrm{O}_{5}$ was significantly influenced by effect of FYM. Treatment $F_{1}$ was recorded significantly highest available $\mathrm{P}_{2} \mathrm{O}_{5}\left(44.66 \mathrm{kgha}^{-1}\right)$ as compared to the control $\mathrm{F}_{0}\left(38.89 \mathrm{kgha}^{-1}\right)$.

The application of FYM had helped in maintaining P content in soil. Similar results were reported earlier by Jat et al.(2012a) ${ }^{[4]}$, Ranpariya et al. (2017) ${ }^{\text {[9] }}$ and Rekha et al. (2018) ${ }^{[10]}$.
Data revealed that available $\mathrm{K}_{2} \mathrm{O}$ in soil after the harvest significantly influenced by effect of FYM. Significantly higher available $\mathrm{K}_{2} \mathrm{O}$ was recorded in treatment $\mathrm{F}_{1}(306.5$ $\mathrm{kgha}^{-1}$ ) over control $\mathrm{F}_{0}\left(289.0 \mathrm{kgha}^{-1}\right)$. (table-2)

Data indicated that an application of farm yard manure significantly influence the availability of exchangeable Ca$\mathrm{Mg}$ in soil after harvest of greengram. Significantly the higher exchangeable Ca-Mg (42.32 me100-1 $\mathrm{g}$ soil \& $13.60 \mathrm{me} 100^{-1}$ $\mathrm{g}$ soil) was recorded under treatment $F_{1}$ over $F_{0}$ control, respectively. This is due to slow release of the $\mathrm{Ca}$ and $\mathrm{Mg}$ like secondary nutrient increase their availability after harvest of greengram crop.

Data revealed that available $S$ in soil after the harvest significantly influenced by application of FYM. Significantly higher available $S$ were recorded in treatment $F_{1}(15.82 \mathrm{mg} \mathrm{kg}$ 1) over control $\mathrm{F}_{0}\left(14.43 \mathrm{mg} \mathrm{kg}^{-1}\right)$.

Application of FYM helped in maintaining the available $\mathrm{S}$ status in soil while maximum $\mathrm{S}$ depletion was seen in control. Similar findings were reported by Ranpariya et al. (2017) ${ }^{[9]}$ and Rekha et al. (2018) ${ }^{[10]}$.

The effects of FYM significantly influenced the available $\mathrm{Fe}$ in the soil after harvesting. $F_{1}$ recorded significantly higher available Fe content in soil (21.01 $\mathrm{mg} \mathrm{kg}^{-1}$ ) over control (19.79 $\mathrm{mg} \mathrm{kg}^{-1}$ ).

The effects of farm yard manure significantly influenced the available $\mathrm{Zn}$ in the soil after harvesting. $\mathrm{F}_{1}$ recorded significantly higher available $\mathrm{Zn}$ content in soil $(0.908 \mathrm{mg} \mathrm{kg}$ $\left.{ }^{1}\right)$ over control $\left(0.785 \mathrm{mg} \mathrm{kg}^{-1}\right)$.

\subsection{Effect of bio-fertilizer}

Data presented table-2 revealed that bio-fertilizer did not significantly influence on available $\mathrm{N}$ and $\mathrm{K}_{2} \mathrm{O}$ status of soil after harvest.

The effect of PSB inoculation significantly influenced the available $\mathrm{P}_{2} \mathrm{O}_{5}$ in soil after the harvest. Available $\mathrm{P}_{2} \mathrm{O}_{5}$ was recorded by treatment $\mathrm{B}_{1}\left(43.94 \mathrm{kgha}^{-1}\right)$ was significant higher over control $\mathrm{F}_{0}\left(39.60 \mathrm{kgha}^{-1}\right)$. The increase in available $\mathrm{P}_{2} \mathrm{O}_{5}$ under PSB inoculated treatment was expected due to solubilizing effect of phospho-bacteria, it convert unavailable phosphorus into available form. The results were in accordance with the finding of Dhakal et al. (2016).

A perusal of data indicated that the availability of all other nutrient content $(\mathrm{K}, \mathrm{Ca}, \mathrm{Mg}, \mathrm{S}, \mathrm{Fe}, \mathrm{Mn}, \mathrm{Zn}$ and $\mathrm{Cu}$ ) was not significantly influenced by the inoculation of PSB.

\subsection{Interaction effect}

Interaction effects between phosphorus, FYM and biofertilizer on available $\mathrm{N}$ and available $\mathrm{K}_{2} \mathrm{O}$ status in soil after harvest were found non-significant.

In the case of available $\mathrm{P}_{2} \mathrm{O}_{5}$ in soil after harvest there were none of interaction effects between phosphorus, FYM and bio-fertilizer showed their significant differences on available $\mathrm{P}_{2} \mathrm{O}_{5}$ in the soil after harvest of greengram except $\mathrm{P} \times \mathrm{F} \times \mathrm{B}$ combination. The combination of $\mathrm{P}_{2} \mathrm{~F}_{1} \mathrm{~B}_{1}$ gave a significantly higheravailable $\mathrm{P}_{2} \mathrm{O}_{5}\left(53.95 \mathrm{kgha}^{-1}\right)$ over rest of the treatment combination. This is due to synergetic effect of phosphorus fertilizer, farm yard manure and PSB which increase the available $\mathrm{P}_{2} \mathrm{O}_{5}$ in soil. Similar result was reported earlier by Heisnam et al. (2017) ${ }^{[2]}$.

In the case of available $S$ in soil after harvest there were none of interaction effects between phosphorus, FYM and biofertilizer showed their significant differences on available $S$ in the soil after harvest of greengram 
Data showed that the effect of different interactions effects between phosphorus, farm yard manure and bio-fertilizer on micronutrient ( $\mathrm{Fe}, \mathrm{Mn}, \mathrm{Cu}$ and $\mathrm{Zn}$ ) were also found nonsignificant.

\subsection{Effect on pH, EC and OC}

Data given in table 1 revealed that the effect of phosphorus, FYM and bio fertilizer on $\mathrm{pH}, \mathrm{EC}$ and organic $\mathrm{C}$ content in soil after harvesting was found non-significant.

Table 1: Effect of various treatments on $\mathrm{EC}, \mathrm{pH}$ and $\mathrm{OC}$ after harvest of greengram.

\begin{tabular}{|c|c|c|c|}
\hline Treatments & $\mathrm{EC}\left(\mathrm{dSm}^{-1}\right)$ & pH & $\mathrm{OC}(\%)$ \\
\hline \multicolumn{4}{|c|}{ Phosphorus (P) } \\
\hline $\mathrm{P}_{0}-0 \mathrm{P}_{2} \mathrm{O}_{5} \mathrm{~kg} \mathrm{ha}^{-1}$ & 0.47 & 7.22 & 0.77 \\
\hline $\mathrm{P}_{1}-20 \mathrm{P}_{2} \mathrm{O}_{5} \mathrm{~kg} \mathrm{ha}^{-1}$ & 0.48 & 7.25 & 0.77 \\
\hline $\mathrm{P}_{2}-40 \mathrm{P}_{2} \mathrm{O}_{5} \mathrm{~kg} \mathrm{ha}^{-1}$ & 0.48 & 7.26 & 0.77 \\
\hline S.Em \pm & 0.005 & 0.09 & 0.007 \\
\hline $\mathrm{CD}$ at $5 \%$ & NS & NS & NS \\
\hline \multicolumn{4}{|c|}{ FYM (F) } \\
\hline $\mathrm{F}_{0}-0 \mathrm{tha}^{-1}$ & 0.47 & 7.20 & 0.76 \\
\hline$F_{1}-5 t_{h a}^{-1}$ & 0.48 & 7.28 & 0.78 \\
\hline S.Em \pm & 0.004 & 0.07 & 0.005 \\
\hline $\mathrm{CD}$ at $5 \%$ & $\mathrm{NS}$ & NS & NS \\
\hline \multicolumn{4}{|c|}{ Bio fertilizer (B) } \\
\hline $\mathrm{B}_{0}-$ No inoculation & 0.48 & 7.25 & 0.77 \\
\hline $\mathrm{B}_{1}-\mathrm{PSB}$ inoculation & 0.48 & 7.24 & 0.77 \\
\hline S.Em \pm & 0.004 & 0.07 & 0.006 \\
\hline $\mathrm{CD}$ at $5 \%$ & NS & NS & NS \\
\hline
\end{tabular}

Table 2: Effect of various treatments on available Macro-nutrients in soil after harvest of greengram

\begin{tabular}{|c|c|c|c|c|c|c|}
\hline \multirow{2}{*}{ Treatments } & \multicolumn{6}{|c|}{ Available Macro nutrients } \\
\hline & $\mathbf{N}(\mathrm{kg} / \mathrm{ha})$ & $\mid \mathrm{P}_{2} \mathrm{O}_{5}(\mathrm{~kg} / \mathrm{ha})$ & $\mathrm{K}_{2} \mathrm{O}(\mathrm{kg} / \mathrm{ha})$ & Ex. Ca (me/100 g soil) & Ex. Ca (me/100 g soil) & Available S (mg/kg) \\
\hline \multicolumn{7}{|c|}{ 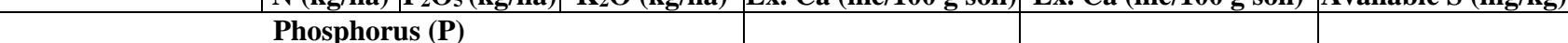 } \\
\hline $\mathrm{P}_{0}-0 \mathrm{P}_{2} \mathrm{O}_{5} \mathrm{~kg} \mathrm{ha}^{-1}$ & 267.7 & 37.72 & 292.8 & 38.08 & 12.24 & 14.77 \\
\hline $\mathrm{P}_{1}-20 \mathrm{P}_{2} \mathrm{O}_{5} \mathrm{~kg} \mathrm{ha}^{-1}$ & 272.1 & 40.14 & 297.9 & 39.56 & 12.72 & 15.02 \\
\hline $\mathrm{P}_{2}-40 \mathrm{P}_{2} \mathrm{O}_{5} \mathrm{~kg} \mathrm{ha}^{-1}$ & 275.2 & 47.45 & 302.6 & 40.44 & 13.00 & 15.59 \\
\hline S.Em \pm & 4.28 & 0.55 & 4.64 & 0.69 & 0.22 & 0.30 \\
\hline CD at $5 \%$ & NS & 1.62 & NS & NS & NS & NS \\
\hline \multicolumn{7}{|c|}{ FYM (F) } \\
\hline $\mathrm{F}_{0-} 0 \mathrm{t} \mathrm{ha}^{-1}$ & 262.4 & 38.89 & 289.0 & 36.40 & 11.70 & 14.43 \\
\hline$F_{1}-5 t_{h a}^{-1}$ & 280.9 & 44.66 & 306.5 & 42.32 & 13.60 & 15.82 \\
\hline S.Em \pm & 3.49 & 0.45 & 3.78 & 0.57 & 0.18 & 0.24 \\
\hline $\mathrm{CD}$ at $5 \%$ & 10.2 & 1.33 & 11.10 & 1.66 & 0.53 & 0.71 \\
\hline \multicolumn{7}{|c|}{ Bio fertilizer $(\mathbf{B})$} \\
\hline $\mathrm{B}_{0}-$ No inoculation & 267.7 & 39.60 & 294.5 & 38.55 & 12.40 & 14.78 \\
\hline $\mathrm{B}_{1}-\mathrm{PSB}$ inoculation & 275.6 & 43.94 & 301.1 & 40.17 & 12.91 & 15.48 \\
\hline S.Em \pm & 3.49 & 0.45 & 3.78 & 0.57 & 0.18 & 0.24 \\
\hline CD at $5 \%$ & NS & 1.33 & NS & NS & NS & NS \\
\hline \multicolumn{7}{|c|}{ Interaction } \\
\hline $\mathrm{P} \times \mathrm{F}$ S.Em \pm & 6.05 & 0.78 & 6.56 & 0.98 & 0.32 & 0.42 \\
\hline $\mathrm{CD}$ at $5 \%$ & NS & NS & NS & NS & NS & NS \\
\hline P $\times$ B S.Em \pm & 6.05 & 0.78 & 6.56 & 0.98 & 0.32 & 0.42 \\
\hline $\mathrm{CD}$ at $5 \%$ & NS & NS & NS & NS & NS & NS \\
\hline $\mathrm{F} \times$ B S.Em \pm & 4.94 & 0.64 & 5.35 & 0.80 & 0.26 & 0.34 \\
\hline $\mathrm{CD}$ at $5 \%$ & NS & NS & NS & NS & NS & NS \\
\hline $\mathrm{P} \times \mathrm{F} \times \mathrm{B}$ S.Em \pm & 8.55 & 1.11 & 9.27 & 1.39 & 0.46 & 0.59 \\
\hline $\mathrm{CD}$ at $5 \%$ & NS & 3.25 & NS & NS & NS & NS \\
\hline CV (\%) & 5.45 & 4.59 & 5.39 & 6.10 & 6.10 & 6.81 \\
\hline Initial status & 307.3 & 42.3 & 326.5 & 40.27 & 14.79 & 15.62 \\
\hline
\end{tabular}

Table 3: Interaction effect ( $\mathrm{P} \times \mathrm{F} \times \mathrm{B})$ available $\mathrm{P} 2 \mathrm{O} 5$ in soil after harvest of greengram

\begin{tabular}{|c|c|c|c|c|}
\hline \multirow{2}{*}{ Phosphorus } & \multicolumn{4}{|c|}{ Available $\mathbf{P}_{\mathbf{2}} \mathbf{O}_{\mathbf{5}}\left(\mathbf{k g ~ h a}^{-1}\right)$} \\
\cline { 2 - 5 } & \multicolumn{3}{|c|}{$\mathbf{F}_{\mathbf{0}}$} & $\mathbf{B}_{\mathbf{1}}$ \\
\cline { 2 - 5 } & $\mathbf{B}_{\mathbf{0}}$ & $\mathbf{B}_{\mathbf{1}}$ & 40.35 & $\mathbf{B}_{\mathbf{1}}$ \\
\hline $\mathrm{P}_{0}-0 \mathrm{P}_{2} \mathrm{O}_{5} \mathrm{kgha}^{-1}$ & 33.07 & 38.46 & 40.44 & 46.03 \\
\hline $\mathrm{P}_{1}-20 \mathrm{P}_{2} \mathrm{O}_{5} \mathrm{~kg} \mathrm{ha}^{-1}$ & 34.37 & 39.25 & 47.65 & 53.65 \\
\hline $\mathrm{P}_{2}-40 \mathrm{P}_{2} \mathrm{O}_{5} \mathrm{~kg} \mathrm{ha}^{-1}$ & 41.75 & 46.47 & \multicolumn{3}{|c|}{} \\
\hline S.Em \pm & \multicolumn{5}{|c|}{3.25} \\
\hline CD at 5\% & \multicolumn{5}{|c|}{} \\
\hline
\end{tabular}


Table 4: Effect of various treatments on DTPA extractable available micronutrient ( $\mathrm{Fe}, \mathrm{Mn}, \mathrm{Zn}$ and $\mathrm{Cu})$ in soil after harvest of greengram.

\begin{tabular}{|c|c|c|c|c|}
\hline \multirow{2}{*}{ Treatments } & \multicolumn{4}{|c|}{ DTPA extractable } \\
\hline & $\mathbf{F e}$ & Mn & $\mathbf{Z n}$ & $\mathbf{C u}$ \\
\hline \multicolumn{5}{|c|}{ Phosphorus (P) } \\
\hline $\mathrm{P}_{0}-0 \mathrm{P}_{2} \mathrm{O}_{5} \mathrm{~kg} \mathrm{ha}^{-1}$ & 19.99 & 21.92 & 0.826 & 2.353 \\
\hline $\mathrm{P}_{1}-20 \mathrm{P}_{2} \mathrm{O}_{5} \mathrm{~kg} \mathrm{ha}^{-1}$ & 20.27 & 22.23 & 0.839 & 2.361 \\
\hline $\mathrm{P}_{2}-40 \mathrm{P}_{2} \mathrm{O}_{5} \mathrm{~kg} \mathrm{ha}^{-1}$ & 20.93 & 22.54 & 0.874 & 2.406 \\
\hline S.Em \pm & 0.38 & 0.42 & 0.013 & 0.034 \\
\hline $\mathrm{CD}$ at $5 \%$ & NS & NS & NS & $\mathrm{NS}$ \\
\hline \multicolumn{5}{|c|}{ FYM (F) } \\
\hline $\mathrm{F}_{0}-0 \mathrm{t} \mathrm{ha}^{-1}$ & 19.79 & 21.73 & 0.785 & 2.335 \\
\hline$F_{1}-5 t_{h a}^{-1}$ & 21.01 & 22.73 & 0.908 & 2.412 \\
\hline S.Em \pm & 0.31 & 0.34 & 0.011 & 0.028 \\
\hline $\mathrm{CD}$ at $5 \%$ & 0.92 & NS & 0.032 & NS \\
\hline \multicolumn{5}{|c|}{ Bio fertilizer (B) } \\
\hline $\mathrm{B}_{0}-$ No inoculation & 20.01 & 21.83 & 0.830 & 2.340 \\
\hline $\mathrm{B}_{1}-\mathrm{PSB}$ inoculation & 20.79 & 22.63 & 0.861 & 2.404 \\
\hline S.Em \pm & 0.31 & 0.34 & 0.011 & 0.028 \\
\hline $\mathrm{CD}$ at $5 \%$ & NS & NS & NS & NS \\
\hline \multicolumn{5}{|c|}{ Interaction } \\
\hline $\mathrm{P} \times \mathrm{F}$ S.Em \pm & 0.54 & 0.59 & 0.019 & 0.048 \\
\hline $\mathrm{CD}$ at $5 \%$ & NS & NS & NS & NS \\
\hline $\mathrm{P} \times$ B S.Em \pm & 0.54 & 0.59 & 0.019 & 0.048 \\
\hline $\mathrm{CD}$ at $5 \%$ & NS & NS & NS & NS \\
\hline F×B S.Em \pm & 0.44 & 0.48 & 0.015 & 0.039 \\
\hline $\mathrm{CD}$ at $5 \%$ & NS & NS & NS & NS \\
\hline $\mathrm{P} \times \mathrm{F} \times \mathrm{B}$ S.Em \pm & 0.76 & 0.84 & 0.027 & 0.068 \\
\hline $\mathrm{CD}$ at $5 \%$ & NS & NS & NS & NS \\
\hline $\mathrm{CV}(\%)$ & 6.49 & 6.52 & 5.58 & 5.02 \\
\hline Initial status & 19.56 & 20.53 & 0.83 & 2.36 \\
\hline
\end{tabular}

\section{Conclusion}

From the result of experimentation, it can be concluded that greengram (Var. Meha) should be fertilized with application of P2O5 @ $20 \mathrm{~kg}$ ha-1 along with FYM @ 5 t ha-1 and seed inoculation $10 \mathrm{ml} \mathrm{kg-1}$ seed with PSB in summer season under south Gujarat condition for getting higher yield, profit and maintenance the soil fertility.

\section{References}

1. Anonymous. Economic Survey of Government of India, 2012.

2. Anonymous. Ministry of Agriculture and Co-operation, GOI. Agriculture Statistics at a glance, 2012a.

3. Heisnam P, Sah D, Moirangthem A, Singh MC, Pandey PK, Mahato NK et al. Effects of Rhizobium, PSB Inoculation and Phosphorus Management on Soil Nutrient Status and Performance of Cowpea in Acid Soil of Arunachal Pradesh, India. Int. J Curr. Microbiol. App. Sci. 2017; 6(8):937-942.

4. Jat A, Arvadia MK, Tandel B, Patel TU, Mehta RS. Response of saline water irrigated greengram to land configuration, fertilizers and farm yard manure in Tapi command area of South Gujarat. Indian Journal of Agronomy. 2012a; 57(3):270-274.

5. Kokani JM, Shah KA, Tandel BM, Bhimani GJ. Effect of fym, phosphorus and sulphur on yield of sumeerblackgram and post-harvest nutrient status of soil. The Bioscan. 2015; 10(1):379-383.

6. Mohammad I, Yadav BL, Ahamad A. Effect of Phosphorus and Bio-Organics on Yield and Soil Fertility Status of Mungbean [Vigna radiata (L.) Wilczek Under SemiArid Condition of Rajasthan, India. International Journal of Current Microbiology and Applied Sciences. 2017; 6(3):1545-1553.
7. Nyekha N, Sharma YK, Sharma SK, Gupta RC. Influence of phosphorus and phosphorus solubilising bacteria on performance of green gram and soil properties. Annals of Plant and Soil Research. 2015; 17(3):323-325.

8. Olsen SR, Cole CV, Watanabe FS, Dean LA. Estimation of available phosphorus in soils by extraction with sodium bicarbonate. USDA Circular 939. U. S. Government Printing Office, Washington D.C, 1954.

9. Ranpariya VS, Polara KB, Hirpara DV, Bodar KH. Effect of potassium, zinc and FYM on content and uptake of nutrients in seed of summer greengram (Vigna radiata L.) and post-harvest soil fertility under medium black calcareous soil. Indian Journal of Chemical Studies. 2017; 5(5):1055-1058.

10. Rekha K, Pavaya RP, Malav JK, Chaudhary N, Patel IM, Patel JK. Effect of FYM, phosphorus and PSB on yield, nutrient content and uptake by greengram (Vigna radiata (L.) Wilckzek) on loamy sand. Indian Journal of Chemical Studies. 2018; 6(2):1026-1029.

11. Thenua OVS, Sharma P. Effect of intercropping, phosphorus levels and bio-fertilizers on the performance of blackgram. Annals Agricultural Research (New Series). 2007; 28(3-4):213-218.

12. Venkateswarlu B. Land configurations and fertilizer management for sustainable groundnut production. Ph.D. thesis. Gujarat Agricultural University, Sardar Krishinagar, Gujarat, 2000. 